\title{
Review Article \\ The Structural Framework of the Erlangping Group in North Qinling, Central China
}

\author{
Hongyuan Zhang, ${ }^{1,2}$ Chunqiang Zhao, ${ }^{1,2}$ Fanglei Xu, , ${ }^{1,2}$ and Yanlong Dong, \\ ${ }^{1}$ School of the Earth Sciences and Resources, China University of Geosciences, Beijing 100083, China \\ ${ }^{2}$ State Key Laboratory of Geological Processes and Mineral Resources, China University of Geosciences, Beijing 100083, China
}

Correspondence should be addressed to Hongyuan Zhang, zhang-hong-yuan@263.net

Received 30 March 2012; Accepted 4 May 2012

Academic Editor: Yu-Dong Wu

Copyright (C) 2012 Hongyuan Zhang et al. This is an open access article distributed under the Creative Commons Attribution License, which permits unrestricted use, distribution, and reproduction in any medium, provided the original work is properly cited.

\begin{abstract}
As one major unit of the North Qinling tectonic belt, and being located in the north side of the UHP belt between the Yangtze block and the North China block, the Erlangping Group has become one hot research spot because it still keeps records of both plate and inner-continent evolution histories. Three aspects of the Erlangping Group are reviewed. (1) Research history are concluded into three stages, including the determination of rock assemblages before the late 1980s, the regional metamorphism laws solution in the 1990s, and the formation time and tectonic background discussion in the 2000s. (2) Five major controversies and frontier scientific problems have been offered, such as, the deformation ages determination, the Cretaceous tectonic event definition, the determination of the deformation mechanisms and conditions, the kinematic and dynamic nature of the Zhuyangguan-Xiaguan shear zone, and the reconstruction of the evolution and exhumation history. (3) Structural framework of the Erlangping Group is divided into five parts according to our field and laboratory study, including the Erjingou slab, the Damiao-Wantan shear zone, the Huoshenmiao slab, the Xiaozhai-Erlangping shear zone, and the Baoshuping slab. Only the Xiaozhai-Erlangping shear zone has clear kinematic marks of left lateral slip.
\end{abstract}

\section{Introduction}

The Erlangping Group, neighbouring the Qinling Group to the south by the Zhuyangguan-Xiaguan boundary shear zone along where ultra high pressure metamorphic rocks were found near the Guanpo Town, and connecting with the Kuanping Group by the Waxuezi-Qiaoduan shear zone (Figure 1). In recent years, with continuously enriched inner and regional related research achievements [1-20], the Erlangping Group is gradually becoming a hot research area.

\section{Research History}

Conclusions of research records of the Erlangping Group indicate one obvious tendency, that is, from the qualitative research of internal combination before 1980s, role of regional metamorphism and thermochronology in the 1990s, and to the time limit research of the construction and comprehensive study in the 21 st century.
2.1. The Determination of the Rock Assemblage before the Late 1980s. The cross-section from south to north of the Erlangping Group contains the Zimugou Formation, the Baoshuping Formation, the Xiaozhai Formation, the Huoshenmiao Formation, the Damiao Formation, and the Erjingou Formation. And it is a set of construction of a spilite keratophyre-sedimentary clastic flysch [21,22]. During this period, the Erlangping Group was generally considered to be formed in the early Paleozoic according to Radiolarian fossils with the pre-Devonian Liospheridae gen. indet, Stylosphoeridae gen. indet in siliceous rock of the Erlangping Group and 391-467 Ma of K-Ar data of metavolcanic rocks below the flysch layer (formerly called the Waitoushan Formation) [14]. Zonation characteristics of metamorphism within the Erlangping Group were concluded by Liu [23]. Xu et al. [14] determine that sinistral movement occurred at places between Shang county and Guanpo town in the west section of the Zhuyangguan-Xiaguan, but they did not perform any deep research according to that book. 


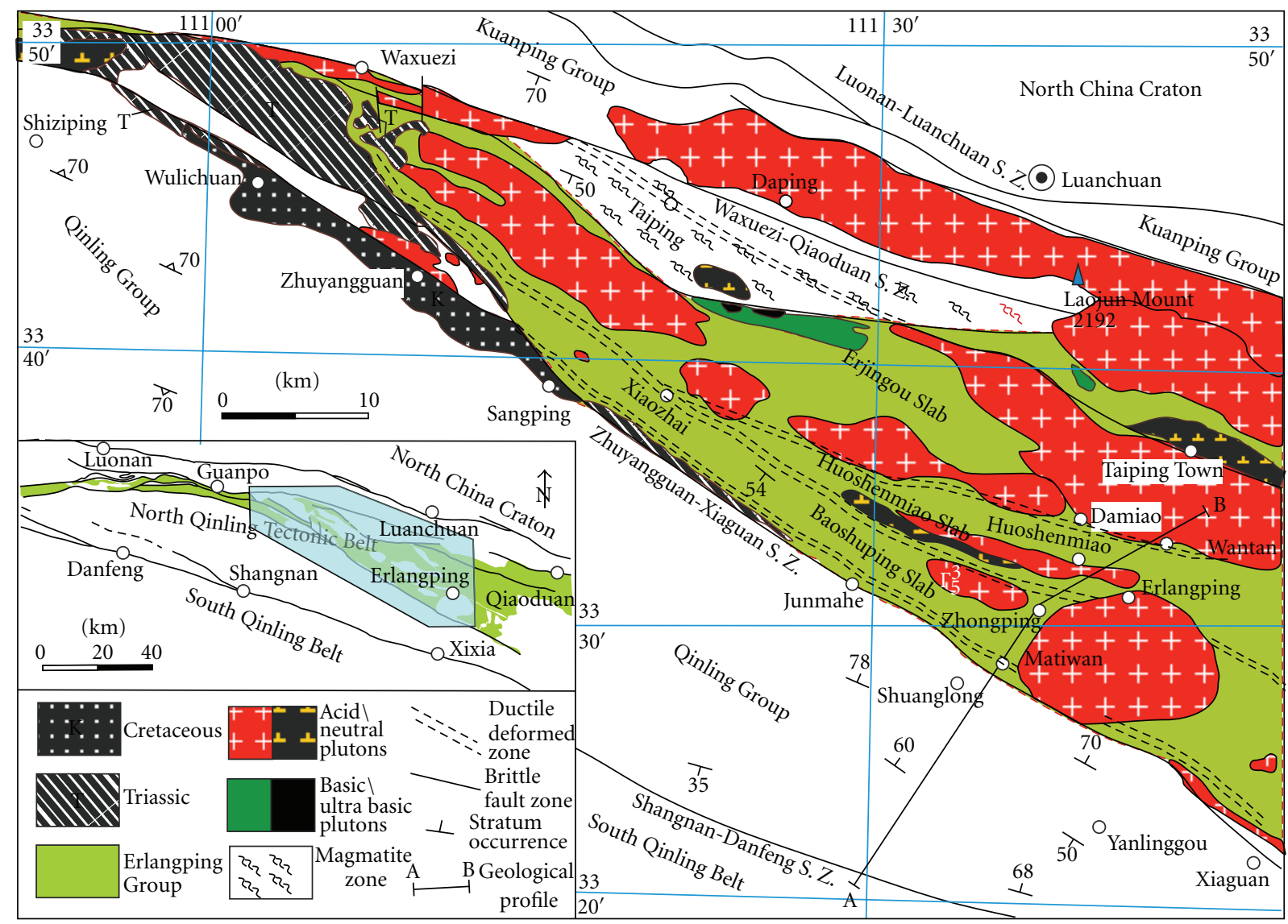

FIgURE 1: Tectonic position of the Erlangping Group in the North Qinling tectonic belt (after [38, 41]).

2.2. The Solution of Regional Metamorphism Laws in the 1990s. During this period, some scholars still hold that the Erlangping Group was formed in the early Paleozoic [24]. However, Pei et al. [25] believed that the Erlangping Group should be formed in the late Paleozoic according to fossils they found. Liu et al. [26] reviewed the metamorphism of the Erlangping Group and found that the wall experienced meso to senior degree of metamorphism with zonation. Regional metamorphism was active in a period ranging from 121.5 to $111.2 \mathrm{Ma}$ according to the metamorphic mineral ${ }^{40} \mathrm{Ar} /{ }^{39} \mathrm{Ar}$ research by Zhao et al. [27], possibly indicating that during the Cretaceous era the whole Qinling orogen are still in its tectonic movement time. As a boundary shear zone of both the Qinling Group and the Erlangping Group, the Zhuyangguan-Xiaguan shear zone was initially emphasized and studied by Suo et al. [28] and Zhong et al. [29], but not much work were carried out inside the Erlangping Group until the late 1990s. Sun et al. [30] reported some zircon $\mathrm{U}-\mathrm{Pb}$ geochronological data indicating an early Ordovician intrusion event from the Xizhuanghe and Baihuling plutons inside the Erlangping Group. Li et al. [31, 32] considered the Erlangping hedge-type thrust and nappe structure eastern to Guanpo as the records of "bidirectional subduction" with meaning of one to the north subduction downward to the Kuanping ancient continent and another to the south downward to the Qinling ancient island arc. However, Wang et al. [33] believed that the total structure framework is like "a composite overturned fold system." The model presented by Wang et al. [33] addresses that the Taiping town principal anticline belt is the central core and that the system is flanked by the Damiao overturned syncline and Zhangjiadazhuang overturned syncline on the south and the Shihuiyao overturned syncline and Penglaojia overturned syncline on the north.

\subsection{The Argument on Formation Time and Tectonic Back-} ground in the 2000s. Since the 21st century, with the development of traditional paleontology and application of new dating technology, focus has been put on determining the formation age and background of the Erlangping Group, and some new academic clues have been obtained through synthesis research of tectonic-magmatic-regional metamorphism.

In general, we believe that the Erlangping Group was constructed in an era ranging from the late-early Paleozoic to the beginning of the late Paleozoic, possibly in Devonian. At the beginning, Zhang et al. [34] summarizes the formation age as ranging from the Late Paleozoic to the Indosinian epoch which could be proved by some Devonian fossils found near Wantan village [35]. However, a small-scale backarc spreading basin in the Early Paleozoic is also one possible 
explanation to the origination of the Erlangping Group by some scholars [36].

In the aspect of structural geology research, definition of the southern boundary of Erlangping Group, however, obviously there are certain contradiction or disagreement with strike-slip structures found in Shangzhou City, Zhuyangguan-Xiaguan, and other places [14, 31, 32]. Zhang et al. [34] considered that the characteristics of the strike-slip structure in the whole Qinling orogenic belt is inconsecutive, penetrability, and small-scale distribution, and addressed a long-term active thrust system which extended from the north to the south as the southern boundary of the Erlangping Group.

Extensive research jobs have been performed on geochronology in subsequent years and are mostly focused on the intrusive rock bodies, which gradually deepened our understanding on the process of deformation and metamorphism within the Erlangping Group. According to results of Tian and Wei [9], at least two major intrusive bodies in the area of the Erlangping Group, including the Banshanping and the Zhangjiazhuang, have been proved to be formed during the period from the Lower Silurian to the early-middle Devonian. The time of the island-arc accretion system in North Qinling appeared has been proven to be existed in the period from the Ordovician to the Carboniferous $[5,6,37]$. Some Paleozoic granite bodies were concluded to be occurred at the North Qinling by thorough analysis on the granite and magma time-space framework model [13]. Several stages, including plate subduction, collision, flower shape extrusion, and dextral strike-slip have been involved into the evolution of the Zhuyangguan-Xiaguan shear zone [13]. Biotite obtained from mylonite rocks near Matiwan village has ${ }^{40} \mathrm{Ar} /{ }^{39} \mathrm{Ar}$ dating results of $106 \mathrm{Ma}$ [38]. Together with the ${ }^{40} \mathrm{Ar} /{ }^{39} \mathrm{Ar}$ data from the Xiaozhai village obtained by Zhao et al. [27], it is reasonable to think of the early Cretaceous event as an exhumation process.

\section{Major Controversies and Problems}

3.1. To Determine Deformation Ages. Although time problems of construction and transformation have been partly resolved by modern isotopic geochronology methods during the past two decades $[7,16,27,39-41]$, it is still extremely difficult to explain chronological data of those geologic bodies that undergone deformation and metamorphism with multistages. To increase the data scale of the several dating methods has become more and more difficult to give an effective resolution of time problems of deformation and metamorphism. To clarify structural stages of deformation rocks is also seriously required before other chronological jobs.

3.2. To Define the Cretaceous Tectonic Event. There is still a problem on how to explain the Cretaceous Ar-Ar chronological data obtained from the Erlangping Group. In our opinion, regional geologic characters and even some Cretaceous structures behaviors in eastern China should benefit to the solution of the problem.
Intracontinental deformation dynamics in central eastern China is a complex process in Cretaceous. Although thrust and nappe structures are very popular crust deformation styles in the region of the Qinling Mountains [34], more obvious strike-slip structures are found to the northeast side of the Qinling Mountains and especially in the Taihang Mountains and Xuhuai region, for example, the TanchengLujiang fault $[42,43]$. Much differently, to the eastern part of north China, the Liaodong Peninsular of northeast China or the southeast coastal area of China, both macroscale of local reduction of lithosphere [44-46] and regional extensional tectonics [47-52] occurred in Cretaceous.

Two major groups of geochronological data in the eastern Jiaodong peninsula are concluded into two groups, about $180 \mathrm{Ma}$ and about $125 \mathrm{Ma}$ separately [53, 54] indicating quite different background, which coincide with the tectonic events of Yanshanian and Sichuanian separately. And similarly, two stages of events were concluded in the Dabie orogenic belt [55]. However, a little different appears in the area of the Erlangping Group, where the Ar-Ar data indicate only the Cretaceous event, seldom Jurassic ones [27, 38, 56]. There are also Cretaceous but seldom Jurassic data in the Qilian-Altin tectonic belt to the west side of the Qinling Mountains [57].

3.3. To Determine Deformation Mechanisms and Conditions. Predecessors concluded some models, including the synclinorium model [33] and the subduction model [31, 32] from the internal framework and the boundary shear zones of the Erlangping Group. How to make the problem clear? According to thoughts of analytical tectonics [58], to study parameter characteristics from aspects including geological geometry, kinematics, dynamics, and rheology and to perform comprehensive quantitative research on the whole tectonic block are essential to figure out the regional structural framework synthetically.

Since the 21st century, microtectonic methods become much popular [59-61]. More and more microscopic quantitative achievements make it possible to study flow mechanics and conditions of tectonites. Some quantitative techniques, including deformation thermometer, deformation stages, deformation dating within a micro area, kinematics of petrofabrics, and rheology have been achieving rapid development in recent years.

Deformation thermometer is a special technique used for deformational temperature testing of ductility deformation rocks. The major types include the crystal shape thermometer, for example, the recrystalline particles size thermometer [62], and the crystallography thermometer, for example, quartz $\mathrm{C}$ axial fabric, and chemistry migratory thermometer, for example, TitaniQ thermometer [63, 64]. Fluid inclusions can also be used to define some conditions of deformation [65-67]. Methods of microchronological dating of deformed rocks have been applied into the orogenic belt $[68,69]$. Petrofabrics and some flow laws (e.g., vorticity and strain rate) [70] of deformation belts can now be conveniently realized by EBSD (the electron backscattered diffraction) methods together with other traditional methods [71-74]. 


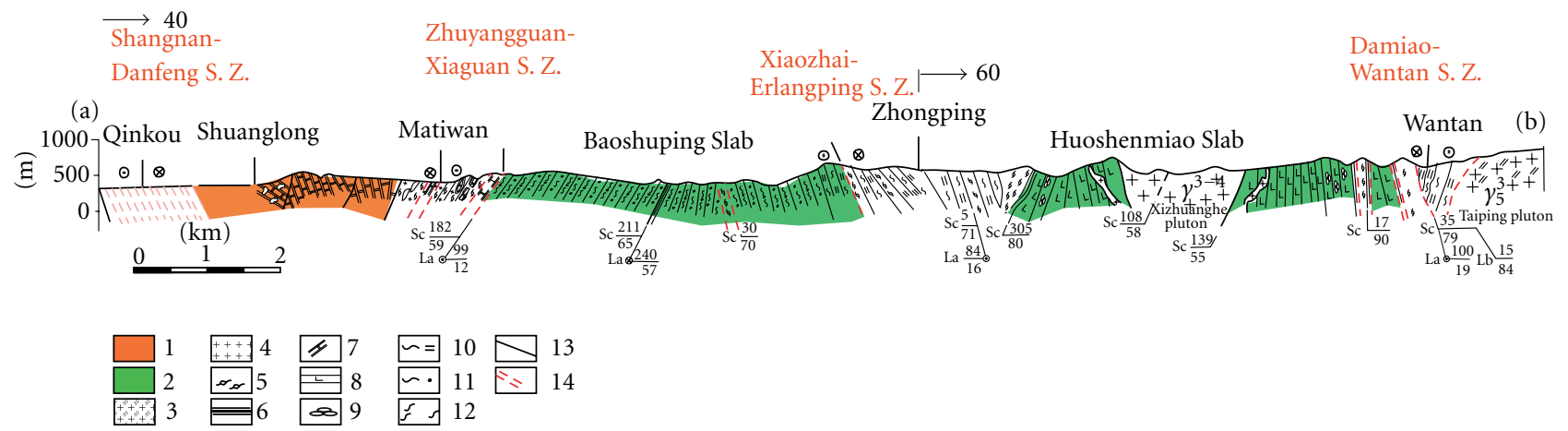

Figure 2: Geological section across the Baoshuping and the Huoshenmiao slabs in the Erlangping Group. 1: the Qinling Group; 2: the Erlangping Group; 3: monzonitic granite; 4: granite; 5: mylonite; 6: siliceous rocks; 7: marble; 8: spilite; 9: pillow-like basalt; 10: two mica schists; 11: biotite schist; 12: high-grade metamorphic rocks; 13: brittle fault zone; 14: ductile shear zone.

3.4. To Define the Nature of the Zhuyangguan-Xiaguan Shear Zone. Has the Zhuyangguan-Xiaguan shear zone experienced pure thrust [34], left-lateral slip [14], right-lateral slip [13], or multistage activities $[31,32,38]$ ? If it is a type of multistage, then whether it belongs to the same process of progressive deformation expression at different part or has experienced progressive overprinting at the same region.

3.5. To Reconstruct Evolution and Exhumation History. Predecessors once hold that there is a central core of anticline in the Taiping town area which transformed the Erlangping Group [33]. But unfortunately, it is just located in the highest level in the mountains. Geologically, there are the Taipingzhen and the Laojunshan acidic intrusive plutons. If exhumation event happened several hundred million years ago, then the outcrop must be in a low valley at present time. Therefore, it is required to get information (e.g., fission track data and Ar-Ar data) from the surface of the earth, which is responding to the exhumation process.

\section{Preliminary Research and Clues}

Interior metamorphism and deformation zonation have been studied [23,38], reflecting macroscopic phenomena transformed by derived structure systems formed by different stages in activities of boundary shear zones of the Erlangping Group. The features of each slab and deformation zone are described from north to south as follows (Figures 1 and 2).

4.1. The North Weak Deformed Field (the Erjingou Slab). Located between the Waxuezi-Qiaorui shear zone and the Damiao-Wantan shear zone, the overall rocks show features of senior metamorphic series and commonly expose migmatitic biotite plagioclase amphibolites gneiss and migmatitic amphibolite remained mass. The original rocks are mainly mafic and neutral types of volcanic rocks. Larger rock masses have been mapped out, such as the Caledonian Zhangjiazhuang (ZJZ), Yanshanian Tangping-Changtanhe (TPCT), Taipingzhen-Manziying (TPMZ), and Yanzhen (YZ).
4.2. The North Strong Deformed Zone (the Damiao-Wantan Shear Zone). The Damiao-Wantan shear zone ranges from NWW $280^{\circ}-\mathrm{SEE} 100^{\circ}$ strike to the east of Xiaozhai village, trends along the southern margin of the Yanzhen mass and the Tangping-Changtanhe mass, and goes to the DamiaoWantan area finally. In the west side of the Xiaozhai village, the shear zone comes together with the Xiaozhai-Erlangping shear zone, another inner strong deformation zone inside the Erlangping Group, which possibly lead to that the Huoshenmiao slab wedged out westward.

Fossil spores of the early-middle Devonian are located in Wantan area [35], with several hundred meters distance south to the Damiao-Wantan shear zone, which is representing the formation state of the Erlangping Group.

Our initial study shows that it experienced at least two stages of transformation. In the traditional Damiao Group, there are mainly phyllonite rocks transformed by movements of the shear zone. The microstructure research from Wantan phyllonite shows significantly fine grained and foliation structures. Inside the foliation domain, the new sericite crystals are popularly born. We preliminarily presumed that the sericite foliation is a mark of rock suffered right-lateral strike-slip shear and is developed earlier than the macroscale duplex structure. In the Wantan area, the diamond blocks and high-angle south-dipped shear foliations are quite clear regionally, showing regional duplex structures with brittleductile deformation.

\subsection{The Middle Weak Deformed Field (the Huoshenmiao} Slab). The Huoshenmiao slab is located between the Damiao-Wantan shear zone and the Xiaozhai-Erlangping shear zone. The main and widest part of it is the WantanErlangping area in the Xixia County of Henan Province. The slab shows an overall wedge geometry and wedges out to west of the Xiaozhai village. The exposed rocks consist of metamorphic mafic volcanic rocks and neutral volcanic rocks (spilite keratophyre). In some areas, primary structures such as pillow basalt, siliceous rocks, and clastic rocks were clearly identified. Gao et al. [35] reported the middle Devonian terrestrial plants Spores, a few suspected Acritarchs and very few Chitinozoa fossils. The slab was also intruded by 
the Caledonian neutral and acidic magmatic rocks, such as the Baihuling diorite mass (BHL) and the Xizhuanghe pale tonalite mass $(\mathrm{XZH})$.

4.4. The South Strong Deformed Zone (the Xiaozhai-Erlangping Shear Zone). The Xiaozhai Formation inside the Erlangping Group was transformed strongly by movement along the Xiaozhai-Erlangping shear zone. Some intrusion relationship marks between the Xiaozhai-Erlangping shear zone and the Erlangping coarse grain granite mass have been recorded according to regional geological survey [21], and our initial study indicated that the rock body has a similar development time to the exhumation of the surrounding slabs. In the shear zone, tectonites were named as sericite schists or two mica schists and observed with left-lateral ductile shear marks. Microscale foliations with biotite enrichment (C) were observed intersecting new muscovite-rich foliations $\left(\mathrm{C}^{\prime}\right)$ at a very low angle, and coming together into a type of $\mathrm{C}-\mathrm{C}^{\prime}$ stretching structure. Occurrence of shear foliations is almost upright, indicating a character of stretch leftlateral strike-slip movement. New muscovite crystals mainly developed in the mica mineral crenulation cleavages, which is possibly caused by local shear heat and related fluid flows.

4.5. The South Weak Deformed Field (the Baoshuping Slab). The Baoshuping slab is located between the XiaozhaiErlangping and the Zhuyangguan-Xiaguan shear zones. The slab has been geologically transformed by low-pressure and middle-temperature metamorphism $[8,75]$. Generally, exposed rocks of the slab can be titled as biotite schists mingled with some amphibolite stripes. But near boundary shear zones of the slab, two mica schists appear more with muscovite content increasing toward outer the slab and especially to the south direction, the Zhuyangguan-Xiaguan shear zone. Protolith of the Baoshuping slab probably includes alkali and tholiitic basaltic series, which possibly experienced two periods of regional metamorphism $[8,75]$. The Yanshanian acid magmatism develops well inside the Baoshuping slab, such as the Gutouya (GTY) and Erlangping (ELP) monzonitic granite masses.

\section{Conclusions}

According to reviews of literatures about North Qinling Erlangping Group and combining our preliminary jobs, some scientific problems, which will be very important to our correct understanding of the Erlangping thermal evolution and even contribute to the regional tectonic evolution, have been concluded as follows:

(1) Composition, banded structure and relationships between the cell structures of the Erlangping Group.

(2) Growth rules of both boundary and internal faults of the Erlangping Group, and their genetic relationship with tectonic evolution of the Erlangping Group.

(3) Magmatic activity within the Erlangping Group and its relationship with regional tectonic evolution.
(4) Thermal-dynamic evolution and exhumation history of the Erlangping Group.

\section{Acknowledgments}

The authors sincerely thank Professor Jun-Lai Liu from China University of Geosciences (in Beijing) for his rectification of the paper. The first author thanks Professor ZongQi Wang and Professor Quan-Ren Yan from the Chinese Academy of Geological Sciences because they gave the first author a lot of professional guidance between 2003 and 2006. The research was supported by "the Fundamental Research Funds for the Central Universities (no. 2-9-2001-280)" and the Chinese National Natural Foundation (no. 90814006 and no. 41030422) of China.

\section{References}

[1] Q. R. Meng and G. W. Zhang, "Geologic framework and tectonic evolution of the Qinling orogen, Central China," Tectonophysics, vol. 323, no. 3-4, pp. 183-196, 2000.

[2] W. Sun, S. Li, Y. Sun, G. Zhang, and Q. Li, "Mid-paleozoic collision in the North Qinling: Sm-Nd, Rb-Sr and ${ }^{40} \mathrm{Ar} /{ }^{39} \mathrm{Ar}$ ages and their tectonic implications," Journal of Asian Earth Sciences, vol. 21, no. 1, pp. 69-76, 2002.

[3] J. S. Yang, Z. Q. Xu, X. Z. Pei et al., "Discovery of diamonds North Qinling: evidence for a giant UHPM belt across Central China and recognition of Paleozoic and mesozoic dual deep subduction between the North China and Yangtze plates," Acta Geologica Sinica, vol. 76, no. 4, pp. 484-495, 2002.

[4] J. S. Yang, Z. Q. Xu, L. F. Dobrzhinetskaya et al., "Discovery of metamorphic diamonds in Central China: an indication of a $>$ 4000-km-long zone of deep subduction resulting from multiple continental collisions," Terra Nova, vol. 15, no. 6, pp. 370-379, 2003.

[5] Z. Q. Wang, T. Wang, Z. Yan, and Q. R. Yan, "Late Paleozoic forearc accretionary piggyback type basin system in the South Qinling, Central China," Geological Bulletin of China, vol. 21, no. 8-9, pp. 456-464, 2002.

[6] Z. Q. Wang, Q. R. Yan, Z. Yan et al., "New division of the main tectonic units of the Qinling orogenic belt, Central China," Acta Geologica Sinica, vol. 83, no. 11, pp. 1527-1546, 2009.

[7] L. Ratschbacher, B. R. Hacker, A. Calvert et al., "Tectonics of the Qinling (Central China): tectonostratigraphy, geochronology, and deformation history," Tectonophysics, vol. 366, no. 12, pp. 1-53, 2003.

[8] A. L. Zhang, C. J. Wei, W. Tian et al., "Low-pressure metamorphism of Erlangping Group in North Qinling Mountains," Acta Petrologica et Mineralogica, vol. 23, no. 1, pp. 26-36, 2004.

[9] W. Tian and C. J. Wei, "The Caledonian low Al-TTD series from the Northern Qinling orogenic belt: rock properties, genetic simulation and geological implication," Science in China, Series D, vol. 48, no. 11, pp. 1837-1847, 2005.

[10] C. Z. Song, M. L. Niu, and G. S. Liu, "Some thoughts on strain research on the Qinling-Dabie orogenic belt," Journal of Hefei University of Technology (Natural Science), vol. 28, no. 7, pp. 719-726, 2005.

[11] C. Z. Song, G. W. Zhang, Y. S. Wang, J. H. Li, Z. C. Chen, and Z. C. Cai, "The constraints of strain partitioning and geochronology in luonan-luanchuan tectonic belts on qinling orogenic belt," Science in China, Series D, vol. 52, no. 3, pp. 300-312, 2009. 
[12] T. Wang, X. Z. Pei, X. X. Wang, N. G. Hu, W. P. Li, and G. W. Zhang, "Orogen-parallel westward oblique uplift of the Qinling basement complex in the core of the Qinling orogen (China): an example of oblique extrusion of deep-seated metamorphic rocks in a collisional orogen," Journal of Geology, vol. 113, no. 2, pp. 181-200, 2005.

[13] T. Wang, X. X. Wang, W. Tian, C. L. Zhang, W. P. Li, and S. Li, "North Qinling Paleozoic granite associations and their variation in space and time: implications for orogenic processes in the orogens of Central China," Science in China, Series D, vol. 52, no. 9, pp. 1359-1384, 2009.

[14] Z. Q. Xu, Y. L. Lu, Y. Q. Tang, and Z. T. Zhang, Formation of the Composite Eastern Qinling Chains, Environmental Science Press, Beijing, China, 1988.

[15] J. F. Xu, Y. W. Han, and B. R. Zhang, "Geochemistry of the Mian-Lue ophiolites in the Qinling Mountains, Central China: constraints on the evolution of the Qinling orogenic belt and collision of the North and South China Cratons," Journal of Asian Earth Sciences, vol. 32, no. 5-6, pp. 336-347, 2008.

[16] F. Wang, X. X. Lu, C. H. Lo et al., "Post-collisional, potassic monzonite-minette complex (Shahewan) in the Qinling Mountains (Central China): ${ }^{40} \mathrm{Ar} /{ }^{39} \mathrm{Ar}$ thermochronology, petrogenesis, and implications for the dynamic setting of the Qinling orogen," Journal of Asian Earth Sciences, vol. 31, no. 2, pp. 153-166, 2007.

[17] X. Wang, T. Wang, B. M. Jahn, N. Hu, and W. Chen, “Tectonic significance of late Triassic post-collisional lamprophyre dykes from the Qinling Mountains (China)," Geological Magazine, vol. 144 , no. 5, pp. 837-848, 2007.

[18] X. Wang, T. Wang, I. Haapala, and J. Mao, "P-T conditions of crystallization and origin of plagioclase-mantled alkali feldspar megacrysts in the Mesozoic granitoids in the Qinling orogen (China)," Lithos, vol. 103, no. 3-4, pp. 289-308, 2008.

[19] S. Lai, J. F. Qin, L. Chen, and R. Grapes, "Geochemistry of ophiolites from the Mian-Lue suture zone: implications for the tectonic evolution of the Qinling orogen, Central China," International Geology Review, vol. 50, no. 7, pp. 650-664, 2008.

[20] Y. P. Dong, G. W. Zhang, F. Neubauer, X. Liu, J. Genser, and C. Hauzenberger, "Tectonic evolution of the Qinling orogen, China: review and synthesis," Journal of Asian Earth Sciences, vol. 41, no. 3, pp. 213-237, 2011.

[21] Henan Provincial Bureau of Geology, $1: 50000$ Northern Xixia County, Regional Geological Survey Report of the People's Republic of China 1-159, 1973.

[22] S. Y. Xiao, W. J. Zhang, Z. J. Song et al., Metamorphic Stratum of the North Qinling, Xi an Jiaotong University Press, 1988.

[23] J. Liu, Metamorphism of the Erlangping Group in the East Qinling [M.S. thesis], The Peking University, 1987.

[24] E. P. Zhang et al., Ed., Overview of Geological-Structural Features in the Qinling-Dabashan Region, Geological Publishing House, Beijing, China, 1993.

[25] F. Pei, Y. G. Zhang, and C. L. Liu, "Discovery and geological significance of the late Paleozoic spore fossils in North Qinling, Henan Province," Regional Geology of China, vol. 2, pp. 112117, 1995.

[26] G. H. Liu, S. G. Zhang, Z. D. You et al., Major Metamorphic Groups and Their Metamorphic Evolution in the Qinling Orogenic Belt, Geological Publishing House, Beijing, China, 1993.

[27] D. L. Zhao, N. G. Hu, and S. Y. An, ${ }^{~}{ }^{40} \mathrm{Ar} /{ }^{39} \mathrm{Ar}$ Plateau age spectra of Erlangping Group, North Qinling and their geological implications," Acta Mineralogica Sinica, vol. 18, no. 1, pp. 101-104, 1998.
[28] S. T. Suo, Z. Q. Zhong, and Y. H. Hu, "Tectonic boundary between Proterozoic and Paleozoic terrains in the Northern part of the Xixia and Neixiang, Henan Province," Scientia Geologica Sinica, vol. 1, pp. 12-21, 1990.

[29] Z. Q. Zhong, Z. D. You, and S. T. Suo, "Petrological study on the ductile shear zones in the core of the Eastern Qinling orogenic belt, Western Henan," Acta Geologica Sinica, vol. 66, no. 2, pp. 121-130, 1990.

[30] Y. Sun, X. X. Lu, S. Han, G. W. Zhang et al., "Composition and formation of Paleozoic Erlangping ophiolitic slab, North Qinling: evidence from geology and geochemistry," Scinece in China, pp. 49-55, 1996.

[31] Y.L. Li, "Geological characteristics of tectonic boundary between Erangping and Qinling Lithologenietic unit in the Northern Qinling Mountain," Geology of Shannxi, vol. 16, no. 2, pp. 9-16, 1998.

[32] Y. L. Li, G. W. Zhang, and C. Z. Song, "Characteristics of Bidirectional subduction of Erlangping Backarc Basin,” Geological Journal of China Universities, vol. 4, no. 3, pp. 286-293, 1998.

[33] M. S. Wang, X. Q. Wu, F. Song et al., "The eastablishment of the main structural framework of the Maoji-Erlangping down-faulted zone in Henan and its significance," Regional Geology of China, vol. 18, no. 1, pp. 23-27, 1999.

[34] G. W. Zhang, B. R. Zhang, X. C. Yuan et al., Qinling Orogenic Belt and Continental Dynamics, Science Press, Beijing, China, 2001.

[35] L. D. Gao, Z. Q. Wang, and T. Wang, "New discovery of spores from the huoshenmiao formation of Erlangping Group, Xixia, Henan Province," Geological Bulletin of China, vol. 25, no. 11, pp. 1287-1294, 2006.

[36] Y. P. Dong, G. W. Zhang, and B. Q. Zhu, "Proterozoic tectonics and evolutionary history of the North Qinling Terrane," Acta Geoscientia Sinica, vol. 24, no. 1, pp. 3-10, 2003.

[37] Q. R. Yan, Z. Q. Wang, Z. Yan et al., “Timing of the transformation from seafloor spreading on the South margin of the North China block to subduction within the North Qinling orogenic belt," Acta Geologica Sinica, vol. 83, no. 11, pp. 15651583, 2009.

[38] H. Y. Zhang, Z. Q. Wang, J. L. Liu et al., "The late Mesozoic extension-slipping-contraction of the Erlangping Group in the North Qinling tectonic belt, Central China," Journal of Geomechanics, vol. 15, no. 1, pp. 56-68, 2009.

[39] N. S. Chen and Z. D. You, "An ${ }^{40} \mathrm{Ar} /{ }^{39} \mathrm{Ar}$ age spectrum of hornblende and its geological significances to Qinling Group in Shewei Area, Western Henan," Acta Petrologica Sinica, vol. 6, no. 4, pp. 54-58, 1990.

[40] Z. Q. Zhang, D. Y. Liu, and G. M. Fu, Isotopic Geochronology on Metamorphic Strata in the Northern Qinling Belt, Geological Publishing House, Beijing, China, 1994.

[41] Z. Q. Zhang, G. W. Zhang, D. Y. Liu et al., Isotopic Geochronology and Geochemistry of Ophioloits, Granites and Clastic Sedimentary Rocks in the Qinling Orogenic Belt, Geological Publishing House, Beijing, China, 2006.

[42] G. Zhu, Y. Wang, G. Liu, M. Niu, C. Xie, and C. Li, " ${ }^{40} \mathrm{Ar} /{ }^{39} \mathrm{Ar}$ dating of strike-slip motion on the Tan-Lu fault zone, East China," Journal of Structural Geology, vol. 27, no. 8, pp. 13791398, 2005.

[43] G. Zhu, D. Jiang, B. Zhang, and Y. Chen, "Destruction of the Eastern North China Craton in a backarc setting: evidence from crustal deformation kinematics," Gondwana Research, vol. 22, no. 1, pp. 86-103, 2012.

[44] F. Y. Wu, J. Q. Lin, S. A. Wilde, X. Zhang, and J. H. Yang, "Nature and significance of the early cretaceous giant igneous 
event in Eastern China," Earth and Planetary Science Letters, vol. 233, no. 1-2, pp. 103-119, 2005.

[45] M. G. Zhai, Q. C. Fan, H. F. Zhang, J. L. Sui, and J. A. Shao, "Lower crustal processes leading to Mesozoic lithospheric thinning beneath Eastern North China: underplating, replacement and delamination," Lithos, vol. 96, no. 1-2, pp. 36-54, 2007.

[46] J. Deng, S. Su, Y. Niu et al., "A possible model for the lithospheric thinning of North China Craton: evidence from the Yanshanian (Jura-Cretaceous) magmatism and tectonism," Lithos, vol. 96, no. 1-2, pp. 22-35, 2007.

[47] T. Wang, Y. Zheng, T. Li, and Y. Gao, "Mesozoic granitic magmatism in extensional tectonics near the Mongolian border in China and its implications for crustal growth," Journal of Asian Earth Sciences, vol. 23, no. 5, pp. 715-729, 2004.

[48] J. Liu, G. A. Davis, L. Zhiyong, and F. Wu, "The Liaonan metamorphic core complex, Southeastern Liaoning Province, North China: a likely contributor to Cretaceous rotation of Eastern Liaoning, Korea and contiguous areas," Tectonophysics, vol. 407, no. 1-2, pp. 65-80, 2005.

[49] J. Liu, H. Guan, M. Ji, and L. Hu, "Late Mesozoic metamorphic core complexes: new constraints on lithosphere thinning in North China," Progress in Natural Science, vol. 16, no. 6, pp. 633-638, 2006.

[50] D. P. Yan, M. F. Zhou, H. L. Song, G. H. Wang, and M. Sun, "Mesozoic extensional structures of the Fangshan tectonic dome and their subsequent reworking during collisional accretion of the North China Block," Journal of the Geological Society, vol. 163, no. 1, pp. 127-142, 2006.

[51] G. Xing, Q. Lu, R. Chen et al., "Study on the ending time of Late Mesozoic tectonic regime transition in south China-comparing to the Yanshan area in North China," Acta Geologica Sinica, vol. 82, no. 4, pp. 451-463, 2008.

[52] W. Lin, P. Monié, M. Faure et al., "Cooling paths of the NE China crust during the Mesozoic extensional tectonics: example from the South-Liaodong peninsula metamorphic core complex," Journal of Asian Earth Sciences, vol. 42, no. 5, pp. 1048-1065, 2011.

[53] H. Y. Zhang, Q. L. Hou, and D. Y. Cao, "Tectono-chronologic constraints on a Mesozoic slip and thrust belt in the Eastern Jiaodong Peninsula," Science in China, Series D, vol. 50, no. 1, pp. 25-32, 2007.

[54] W. Sun, X. Ding, Y. H. Hu, and X. H. Li, "The golden transformation of the Cretaceous plate subduction in the West Pacific," Earth and Planetary Science Letters, vol. 262, no. 3-4, pp. 533-542, 2007.

[55] Q. Hou, Q. Liu, J. Li, and H. Y. Zhang, "Late Mesozoic shear zones and its chronology in the Dabie Mountains, Central China," Scientia Geologica Sinica, vol. 42, no. 1, pp. 114-123, 2007.

[56] Q. D. Xu, Z. Q. Zhong, and F. W. Yang, " ${ }^{40} \mathrm{Ar} /{ }^{39}$ Ar dating of the Xiaoqinling gold area in Henan Province," Geological Review, vol. 44, no. 3, pp. 323-327, 1998.

[57] X. H. Chen, A. Yin, G. E. Gehrels et al., "Two phases of Mesozoic North-South extension in the Eastern Altyn Tagh range, Northern Tibetan Plateau," Tectonics, vol. 22, no. 5, pp. 8-1-8-22, 2003.

[58] X. Y. Ma, “On analytical tectonics," Earth Science-Journal of Wuhan College of Geology, vol. 22, no. 3, pp. 1-9, 1983.

[59] C. Passchier and R. Trouw, Microtectonics, Springer, Berlin, Germany, 2nd edition, 2005.

[60] R. H. Vernon and G. L. Clarke, Principles of Metamorphic Petrology, Cambridge University Press, 2008.
[61] R. A. J. Trouw, C. W. Passchier, and D. J. Wiersma, Atlas of Mylonites- and Related Microstructures, Springer, Berlin, Germany, 2010.

[62] M. Stipp and K. Kunze, "Dynamic recrystallization near the brittle-plastic transition in naturally and experimentally deformed quartz aggregates," Tectonophysics, vol. 448, no. 14, pp. 77-97, 2008.

[63] D. A. Wark and E. B. Watson, "TitaniQ: a titanium-in-quartz geothermometer," Contributions to Mineralogy and Petrology, vol. 152, no. 6, pp. 743-754, 2006.

[64] W. M. Behr and J. P. Platt, "A naturally constrained stress profile through the middle crust in an extensional terrane," Earth and Planetary Science Letters, vol. 303, no. 3-4, pp. 181192, 2011.

[65] E. A. J. Burke, "Raman microspectrometry of fluid inclusions," Lithos, vol. 55, no. 1-4, pp. 139-158, 2001.

[66] V. Lüders, B. Plessen, and R. Primio, "Stable carbon isotopic ratios of $\mathrm{CH}_{4}-\mathrm{CO}_{2}$-bearing fluid inclusions in fracture-fill mineralization from the Lower Saxony Basin (Germany)a tool for tracing gas sources and maturity," Marine and Petroleum Geology, vol. 30, no. 1, pp. 174-183, 2012.

[67] M. Slobodník, R. Melichar, V. Hurai, and R. J. Bakker, "Lithostratigraphic effect on Variscan fluid flow within the Prague synform, Barrandian: evidence based on C, O, Sr isotopes and fluid inclusions," Marine and Petroleum Geology. In press.

[68] Z. G. Mu, "The laser microprobe ${ }^{40} \mathrm{Ar} /{ }^{39} \mathrm{Ar}$ dating method," Earth Science Frontiers, vol. 10, no. 2, pp. 301-307, 2003.

[69] M. Beltrando, G. S. Lister, M. Forster, W. J. Dunlap, G. Fraser, and J. Hermann, "Dating microstructures by the ${ }^{40} \mathrm{Ar} /{ }^{39} \mathrm{Ar}$ step-heating technique: deformation-pressure-temperaturetime history of the Penninic Units of the Western Alps," Lithos, vol. 113, no. 3-4, pp. 801-819, 2009.

[70] E. H. Rutter and K. H. Brodie, "Rheology of the lower crust," in Geology of the Lower Continental Crust, D. Fountain, R. Arculus, and R. Kay, Eds., pp. 201-268, Elsevier, Amsterdam, The Netherlands, 1992.

[71] G. Hirth, C. Teyssier, and J. W. Dunlap, "An evaluation of quartzite flow laws based on comparisons between experimentally and naturally deformed rocks," International Journal of Earth Sciences, vol. 90, no. 1, pp. 77-87, 2001.

[72] H. Stünitz, J. D. Fitz Gerald, and J. Tullis, "Dislocation generation, slip systems, and dynamic recrystallization in experimentally deformed plagioclase single crystals," Tectonophysics, vol. 372, no. 3-4, pp. 215-233, 2003.

[73] L. Mehl and G. Hirth, "Plagioclase preferred orientation in layered mylonites: evaluation of flow laws for the lower crust," Journal of Geophysical Research B, vol. 113, no. 5, Article ID B05202, 2008.

[74] C. Sassier, P. H. Leloup, D. Rubatto, O. Galland, Y. Yue, and D. Lin, "Direct measurement of strain rates in ductile shear zones: a new method based on syntectonic dikes," Journal of Geophysical Research B, vol. 114, no. 1, Article ID B01406, 2009.

[75] H. W. Zhou and N. S. Chen, "Metamorphism, deformation and metamorphic reactions of low-pressure metamorphic belt in East Qinling orogenic belt, Western Henan," Earth Science-Journal of China University of Geosciences, vol. 19, no. 1, pp. 9-18, 1994. 

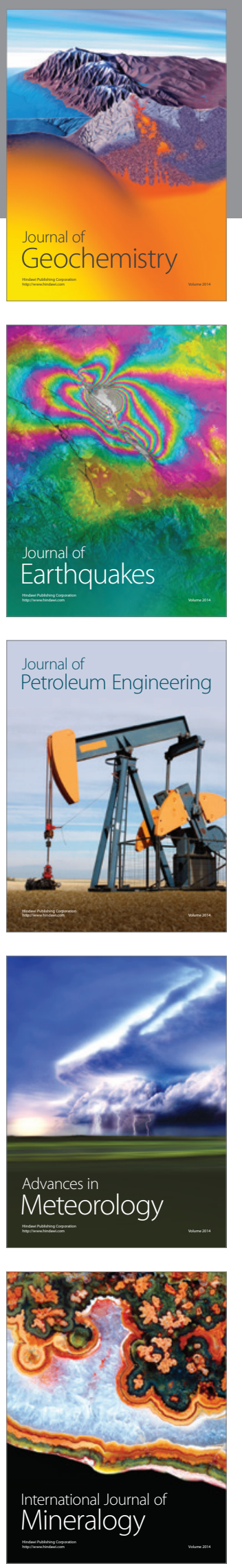
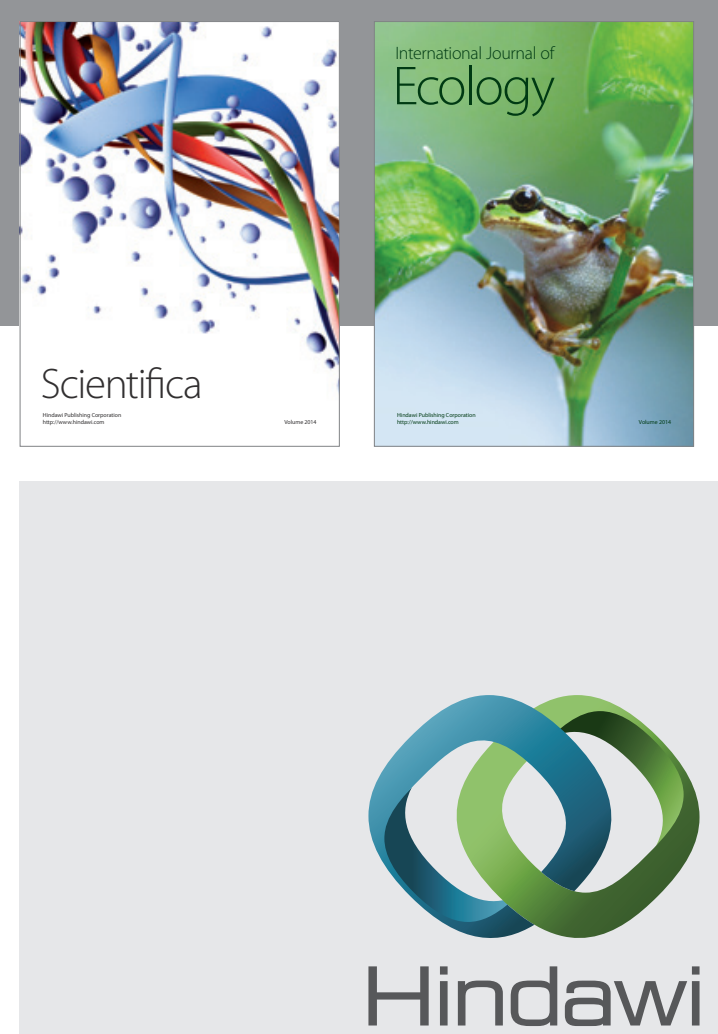

Submit your manuscripts at http://www.hindawi.com
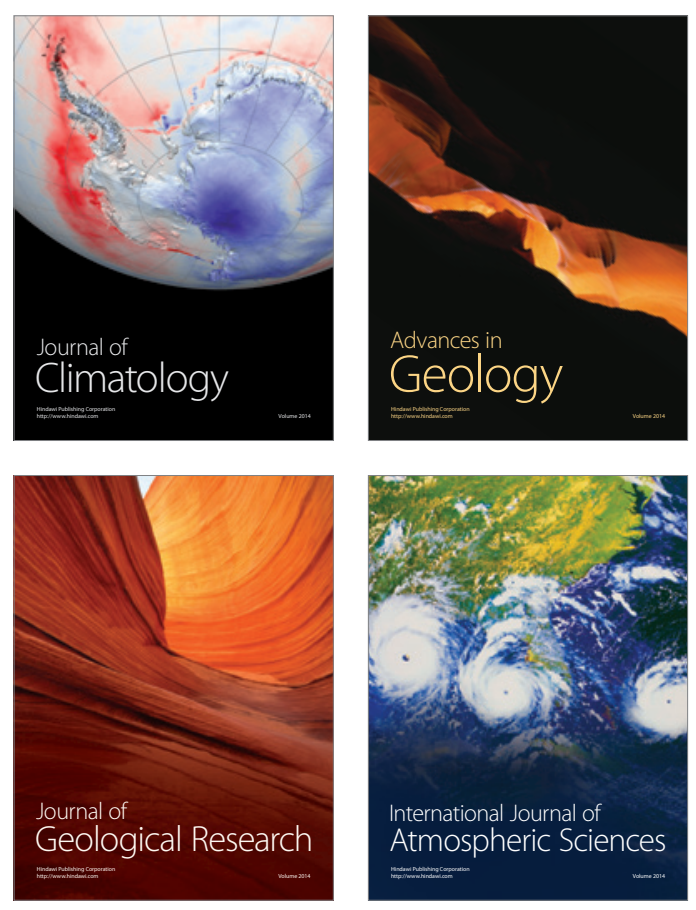
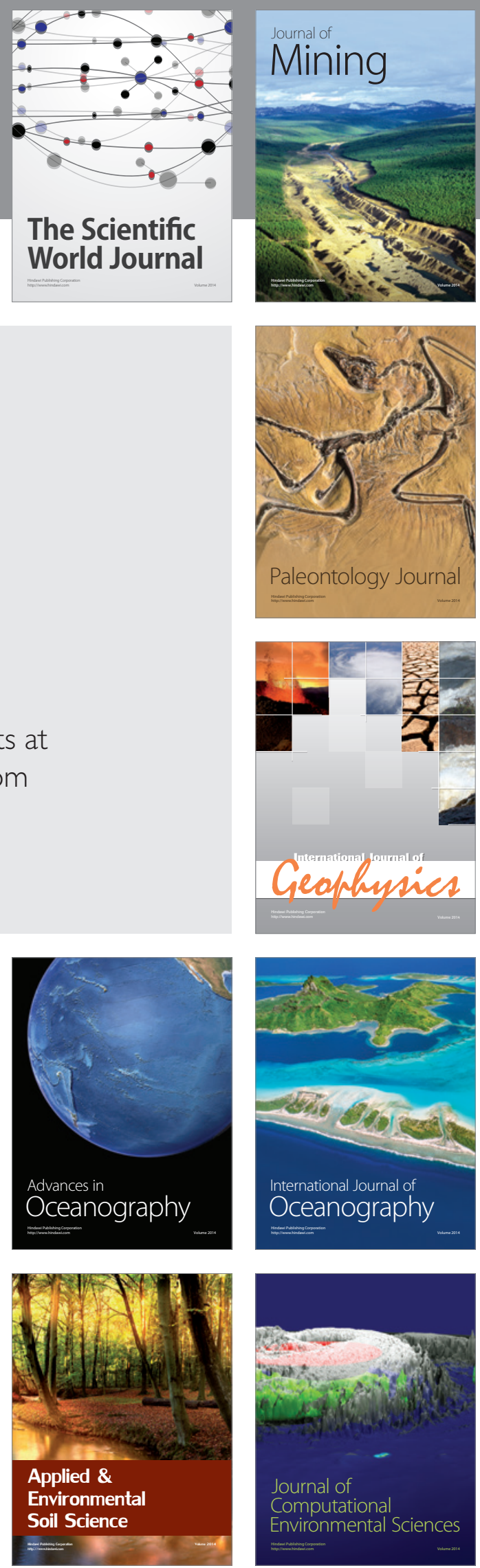